\title{
The effect of fat supplementation of concentrates on digestion and utilization of energy by productive dairy
} cows

\author{
Y. van der Honing, B. J. Wieman, A. Steg and B. van Donselaar \\ Institute for Livestock Feeding and Nutrition Research (IVVO), P.O. Box 160, Le- \\ lystad, the Netherlands
}

Accepted: 27 January 1981

Key words: energy utilization, balance trials, dairy cows, wethers, digestibility, fatenriched concentrates, tallow, soya bean oil

\section{Summary}

The effect of a supplement of 5-7\% tallow or $5 \%$ soya bean oil to a mixture of concentrates on digestibility and utilization of energy was studied in balance trials with dairy cows and wethers. Cows were fed $7 \mathrm{~kg}$ of hay and 11-14 kg of concentrates and the wethers received the ration components of the cows at about the maintenance level of feeding for energy.

Supplementation did not significantly depress energy or fibre digestibility, although this was reported several times in the literature.

Methane losses were slightly lower in the fat-supplemented rations, but the effect of level of feeding on metabolizable energy was fairly comparable to that in the Dutch feed evaluation system.

Soya bean oil depressed the milkfat percentage and energy produced as milk. Utilization of fat-supplemented diets by dairy cows was similar to that of the control diets.

Good quality animal tallow appeared to be helpful in the feeding of high-yielding dairy cows in early lactation.

\section{Introduction}

Especially in early lactation, requirements of high-yielding dairy cows cannot easily be met because of the limited feed intake capacity. Unfortunately this limited intake capacity cannot easily be counterbalanced by feeding energy-rich feeds, because of restrictions to decrease the forage-to-concentrates ratio due to lack of structure of the latter. It has, however, generally been accepted that aiming at maximum intake of nutrients and energy and minimizing the gap between requirement and consumption energy is likely to be profitable for milk yield and efficiency of animal produc- 
tion by cattle of excellent genetic potential for milk production (Broster \& Swan, 1979).

The restricted intake capacity of the high-yielding cow in early lactation does not leave much but to increase its energy intake by increasing the energy density of the ration with feedstuffs with a high fat or oil content. But, in several experiments the addition of fats to ruminant diets was reported to affect the fermentation of feeds in the forestomachs resulting in a decrease of the digestibility of feed components, crude fibre in particular. Changes in the composition of milk and milkfat were also reported (Vanschoubroeck, 1966; Lough, 1975; Rohr et al., 1978). None of these authors, however, was able to point out conclusively which factors are involved and what quantitative relationship existed for the influence of fat supplementation on rumen fermentation, digestion, utilization of the diet and the composition of milk.

Long chain fatty acids, unsaturated in particular, were reported to reduce methane losses and often resulted in increased proprionic acid in the rumen fluid (Czerkawski et al., 1966; Demeyer et al., 1969).

From the literature quite variable effects of fat were reported on digestibility of nutrients, especially of the cell wall constituents with several reports showing a decrease in digestibility when more than 4-5\% of fat was added. High $\mathrm{Ca}$ en $\mathrm{Mg}$ may reduce the negative effect of fat by forming soaps with fatty acids, using a lower proportion of forage in the diet reduced the negative effect too (Rohr et al., 1978). However, at even higher levels of fat supplementation, Johnson \& McClure (1973) and Palmquist (1978), did not find a depression of digestibility.

Effects on yield and composition of milk, the fat percentage in particular, were reported to be positive, absent as well as negative, as reviewed by Rohr et al. (1978).

The large variation in effects of fat must at least partly be caused by the type of fat (the degree of unsaturation, the origin of the fat/oil), the composition of the ration in which fat is included (especially type and proportion of fibrous substances), the degree of technological protection if applied, etc.

Apart from a rather limited knowledge on the mechanism of the effect of fat on rumen metabolism, there is also a lack of information on energy conversion and utilization by high-yielding cows fed with fat supplemented diets. Knowledge of changes in energy utilization, induced by fat supplementation of dairy rations, is important in feed formulation, especially for high-yielding cows in early lactation. The most suitable way to investigate the effects of fat on digestibility and on nitrogen and energy balance are balance trials.

\section{Materials and methods}

Two energy balance experiments were performed in 1977 and 1979, respectively. In each experiment 6 high-yielding dairy cows of the Dutch FH breed were used. The animals in the first experiment were 2-3 months in lactation and produced $24-33 \mathrm{~kg}$ of milk and those in the second experiment were already 5 months in lactation with a production of 18-27 kg of milk.

Experiment $I$ was arranged as a $3 \times 3$ Latin square design with one replicate; Experiment II had a change-over design. Treatments were respectively three (control, 
Table 1. Composition of the concentrate mixtures $(\mathrm{g} / \mathrm{kg})$.

\begin{tabular}{|c|c|c|c|c|c|}
\hline \multirow[t]{2}{*}{ Feedstuff } & \multicolumn{3}{|c|}{ Experiment I } & \multicolumn{2}{|c|}{ Experiment II } \\
\hline & $\mathrm{C}^{1}$ & TI & $\mathrm{S}$ & $\mathrm{C} 2$ & $\mathrm{~T} 2$ \\
\hline soya bean meal, extracted & 250 & 237 & 237 & 145 & 133 \\
\hline coconut cake & 108 & 102 & 102 & 50 & 50 \\
\hline linseed meal, extracted & 100 & 95 & 95 & - & - \\
\hline maize gluten feed & 160 & 152 & 152 & 240 & 223 \\
\hline dried sugar-beet pulp & 200 & 190 & 190 & 170 & 158 \\
\hline citrus pulp & - & - & - & 170 & 158 \\
\hline tapioca/manioc & 100 & 95 & 95 & 110 & 98 \\
\hline sugar-cane molasses & 50 & 47 & 47 & 80 & 80 \\
\hline animal tallow & - & 50 & - & 5 & 70 \\
\hline soya bean oil & - & - & 50 & - & - \\
\hline minerals/vitamines & 27 & 27 & 27 & 25 & 25 \\
\hline $\mathrm{MgO}$ & 5 & 5 & 5 & 5 & 5 \\
\hline \multicolumn{6}{|l|}{ In dry matter } \\
\hline crude protein $(\mathrm{g} / \mathrm{kg})$ & 251 & 235 & 238 & 176 & 168 \\
\hline gross energy $(\mathrm{MJ} / \mathrm{kg})$ & 17.9 & 18.7 & 18.5 & 17.4 & 19.1 \\
\hline
\end{tabular}

1 For explanation see text.

$\mathrm{C} 1$, animal tallow, $\mathrm{T} 1$ and soya bean oil, $\mathrm{S}$ ) and two (control, $\mathrm{C} 2$ and animal tallow, T2) concentrate mixtures.

Diets were composed of $7 \mathrm{~kg}$ of grass hay and $11-14 \mathrm{~kg}$ of mixed concentrates. The composition of the concentrates is presented in Table 1. The fat/oil supplement was added to the control-mixture instead of replacing one or two ingredients in the mixture by fat/oil. Feeding was twice a day, at $06 \mathrm{~h} 00$ and $15 \mathrm{~h} 30$; concentrates were offered before the hay.

In addition to the experiments with dairy cows the digestibility and metabolizable energy of hay and of the 5 concentrate mixtures were determined by using 4 wether sheep fed at about their maintenance level of feeding. Digestibilities of concentrates were measured by difference, using $300 \mathrm{~g}$ of the hay as a basal diet. As usual for the sheep, a 10-day collection period was preceded by an adaptation period of 11 days. Gas exchange measurements were carried out on 4 of the 10 days of the collection period on pairs of two sheep, each in its own metabolism crate, in one chamber.

Experiments with cows started with an adaptation period of 3 weeks followed by a collection period of 10-12 days, of which 4-6 days for gas exchange measurements in respiration chambers of the open-circuit system.

One cow in Exp. I, fitted with a rumen cannula, was used to study rumen fermentation, as measured by $\mathrm{pH}$, buffering capacity and concentrations of volatile fatty acids (VFA) and ammonia in the rumen fluid and rumen liquor dilution rate by using Cr-EDTA (Binnerts et al., 1968).

Samples of feeds and faeces were dried at $65^{\circ} \mathrm{C}$, ground and analysed for dry matter, ash and crude fibre according to the Weende method. Nitrogen in feed and faeces was analysed according to the method of Dumas. Nitrogen in faeces was de- 
Table 2. Dry matter intake $\left(\mathrm{I}_{\mathrm{T}}, \mathrm{kg} /\right.$ day $)$ and its chemical composition $(\mathrm{g} / \mathrm{kg} \mathrm{dm})$ of the respective rations by dairy cows.

\begin{tabular}{lllllll}
\hline Treatment & $\mathrm{I}_{\mathrm{T}}$ & $\mathrm{XP}^{2}$ & $\mathrm{XL}$ & $\mathrm{XF}$ & $\mathrm{XX}$ & $\begin{array}{l}\text { Energy } \\
(\mathrm{MJ} / \mathrm{kg})\end{array}$ \\
$\mathrm{C} 1$ & 17.5 & 224 & 26 & 161 & 500 & 17.9 \\
$\mathrm{~T} 1$ & 17.5 & 214 & 63 & 159 & 478 & 18.6 \\
$\mathrm{~S}$ & 17.4 & 214 & 55 & 156 & 488 & 18.5 \\
$\mathrm{C} 2$ & 15.8 & 186 & 29 & 152 & 531 & 17.9 \\
$\mathrm{~T} 2$ & 15.6 & 182 & 79 & 145 & 497 & 18.9 \\
\hline
\end{tabular}

${ }^{1}$ For explanation see text.

$2 \mathrm{XP}=$ crude protein, $\mathrm{XL}=$ crude fat (hexane extraction), $\mathrm{XF}=$ crude fibre, $\mathrm{XX}=\mathrm{N}$-free extract.

termined in fresh material. Nitrogen in urine and milk was analysed with the Kjeldahl method. Total lipids in feed and faeces were estimated from Soxhlet extraction with di-ethyl ether (Exp. I) and hexane (Exp. I + II). Hexane extraction was also performed after a pre-treatment with $\mathrm{HCl}$ solution to prevent losses of fatty acids as soaps in both experiments. Total energy in feed, faeces, urine and milk was determined by combustion in an adiabatic bomb calorimeter.

\section{Results and discussion}

Table 2 presents the average dry matter intake by the cows as well as the chemical composition of the ingested dry matter. Average intake of dry matter of different rations was equal within experiments, so that the main differences between diets were due to the fat supplementation, as is shown by the content of total lipids and energy in the diets. Lipid analyses were lower than expected, especially in the S-concentrates, but could not be verified due to loss of samples by the fire in the laboratory in 1979 .

\section{Digestibility}

The apparent digestibility coefficients of the hays and concentrate-mixtures from trials with wethers at the maintenance level of feeding are shown in Table 3. Except for lipids $(\mathrm{XL})$ the differences between concentrate mixtures within experiments were not significant. The higher apparent digestibility coefficient of XL is mainly due to the smaller effect of endogenous lipid excretion on apparent fat digestibility because of the increased XL consumption and the supplementation with highly digestible fat/oil. The supplementation with fat/oil did not significantly affect digestibility of other constituents, not even that of crude fibre. This is somewhat surprising because several authors did observe a depression in sheep experiments (Dijkstra, 1969; Buysse, 1962; Cottijn et al., 1971; Devendra \& Lewis, 1974).

Table 4 presents the digestibility of the diets by dairy cows at a higher level of feeding. Within each of the experiments no significant differences between treatments were observed in digestibility of organic matter, crude protein, crude fibre, $\mathrm{N}$-free 
Table 3. Coefficients of digestibility of hay and concentrates fed to 4 wether sheep around the maintenance level of feeding.

\begin{tabular}{llllllll}
\hline Ration component & \multicolumn{6}{l}{ Coefficient of digestibility $(\%)$ of } \\
\cline { 2 - 7 } & $\mathrm{OM}^{1}$ & $\mathrm{XP}$ & $\mathrm{XL}^{2}$ & $\mathrm{XF}$ & $\mathrm{XX}$ & energy \\
Hay, Exp. 1 & 64.8 & 73.2 & 30.0 & 60.7 & 64.7 & $60.5 \pm 1.0$ \\
Hay, Exp. 2 & 72.3 & 74.0 & 55.4 & 73.2 & 72.4 & $68.5 \pm 1.5$ \\
C1 - concentrate & 86.3 & 84.6 & 74.1 & 65.3 & 92.3 & $85.0 \pm 0.6$ \\
$\mathrm{~T} 1$ - concentrate & 85.6 & 82.7 & 89.1 & $58.2^{3}$ & 92.2 & $85.3 \pm 1.6$ \\
$\mathrm{~S}-$ concentrate & 85.3 & 83.2 & 83.0 & $58.7^{3}$ & 91.8 & $84.5 \pm 0.3$ \\
C2 - concentrate & 84.3 & 76.3 & 73.6 & 67.2 & 89.8 & $81.6 \pm 2.0$ \\
T2 - concentrate & 86.0 & 78.2 & 88.5 & 70.0 & 90.3 & $83.7 \pm 0.9$ \\
\hline
\end{tabular}

$1 \mathrm{OM}=$ organic matter, see also Table 2.

${ }^{2}$ Based on extraction with hexane after boiling with $\mathrm{HCl}$ solution to prevent fatty acid losses as soaps.

${ }^{3}$ High standard deviation, due to variable results of XF analysis, which could not be confirmed because of loss of samples due to fire.

Table 4. Digestiblity coefficients (dc) of the rations by the dairy cows and estimate of depression of digestibility $(\Delta)$ due to increased level of feeding (FL) in units of the digestibility coefficient.

\begin{tabular}{|c|c|c|c|c|c|c|c|c|}
\hline \multicolumn{2}{|c|}{ Ration } & OM & XP & $\mathrm{XL}^{1}$ & $\mathrm{XF}$ & $x x$ & Energy & $\mathrm{FL}^{2}$ \\
\hline \multirow[t]{2}{*}{$\mathrm{C} 1$} & $\mathrm{dc}$ & 74.4 & 74.1 & 60.6 & 55.6 & 81.4 & $72.2 \pm 1.2$ & 3.3 \\
\hline & $\Delta$ & 4.9 & 7.7 & 4.0 & 7.2 & 2.9 & 4.7 & \\
\hline \multirow[t]{2}{*}{$\mathbf{T} 1$} & $\mathrm{dc}$ & 74.6 & 72.5 & 79.3 & 55.8 & 81.1 & $73.2 \pm 1.4$ & 3.5 \\
\hline & $\Delta$ & 4.3 & 7.5 & 4.0 & $2.3^{3}$ & 4.1 & 4.3 & \\
\hline \multirow[t]{2}{*}{$\mathrm{S}$} & $\mathrm{dc}$ & 74.1 & 72.6 & 72.7 & 54.5 & 81.1 & $72.0 \pm 1.4$ & 3.4 \\
\hline & $\Delta$ & 4.7 & 8.1 & 4.7 & $5.3^{3}$ & 2.8 & 5.0 & \\
\hline \multirow[t]{2}{*}{$\mathrm{C} 2$} & $\mathrm{dc}$ & 75.2 & 66.9 & 62.2 & 66.2 & 81.4 & $73.2 \pm 1.8$ & 3.1 \\
\hline & $\Delta$ & 4.8 & 8.5 & 5.0 & 4.7 & 3.7 & 3.7 & \\
\hline \multirow[t]{2}{*}{$\mathrm{T} 2$} & $\mathrm{dc}$ & 77.0 & 68.9 & 79.6 & 70.0 & 81.6 & $75.7 \pm 0.8$ & 3.4 \\
\hline & $\Delta$ & 4.3 & 7.7 & 4.7 & 2.0 & 3.7 & 3.0 & \\
\hline
\end{tabular}

${ }^{1}$ Based on hexane extraction after $\mathrm{HCl}$ treatment.

${ }^{2} \mathrm{FL}=$ Feed level expressed as multiple of maintenance level of feeding.

${ }^{3}$ Low precision due to high standard deviation in sheep trial.

extract and energy. These results agree with data of Palmquist \& Conrad (1978, 1980), but not with those of Rohr et al. (1978) in which the tallow-supplemented diet with $950 \mathrm{~g}$ crude fat depressed organic matter and crude fibre digestibility.

Assuming digestibilities at maintenance not to differ between cattle and sheep except for crude protein (XP) (Schiemann et al., 1972) we studied the effect of an increased level of feeding on digestibility for the results obtained with cattle. Table 4 shows the depression of digestibility coefficients in units, derived from a compari- 


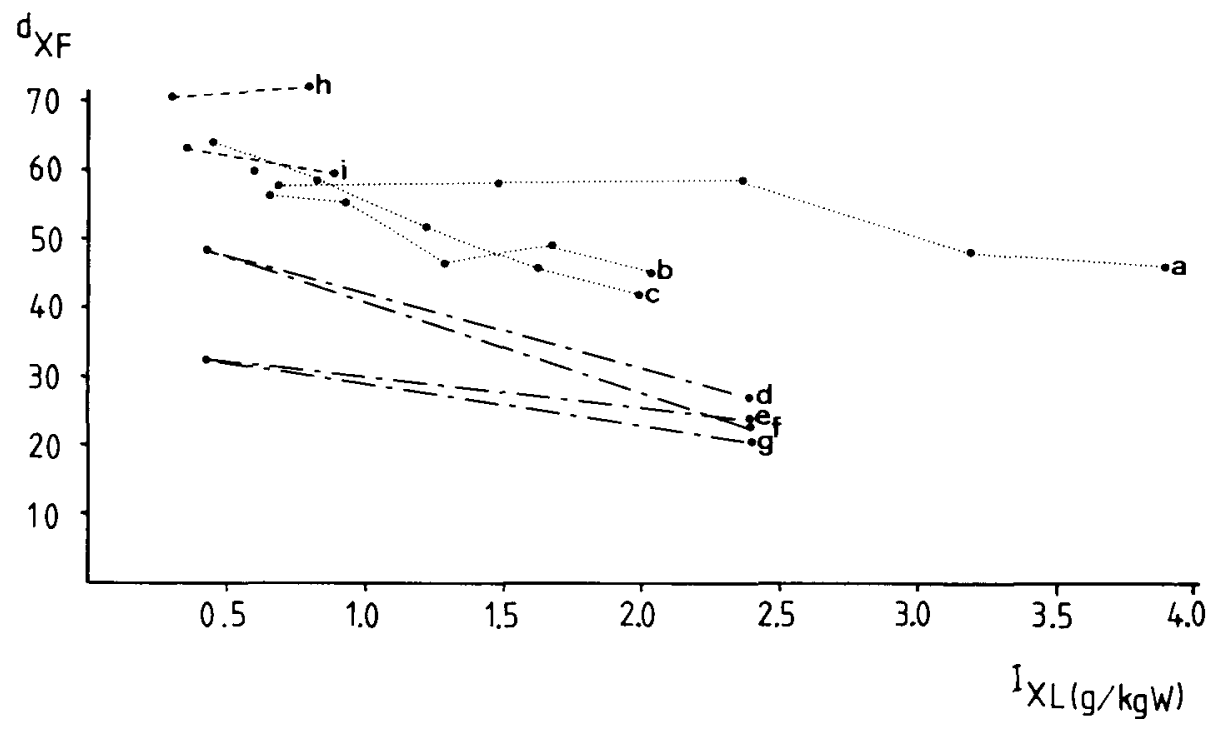

Fig. 1a. Effect of animal fat supplementation on digestibility of crude fibre $\left(d_{X F}\right)$ by wethers versus lipid consumption $\left(\mathrm{I}_{\mathrm{XL}}\right.$ ) in $\mathrm{g} / \mathrm{kg}$ live weight. (From: Dijkstra, 1969: a, b, c; Devendra \& Lewis, 1974: d, e, $f, g$ and this study: $h, i)$.

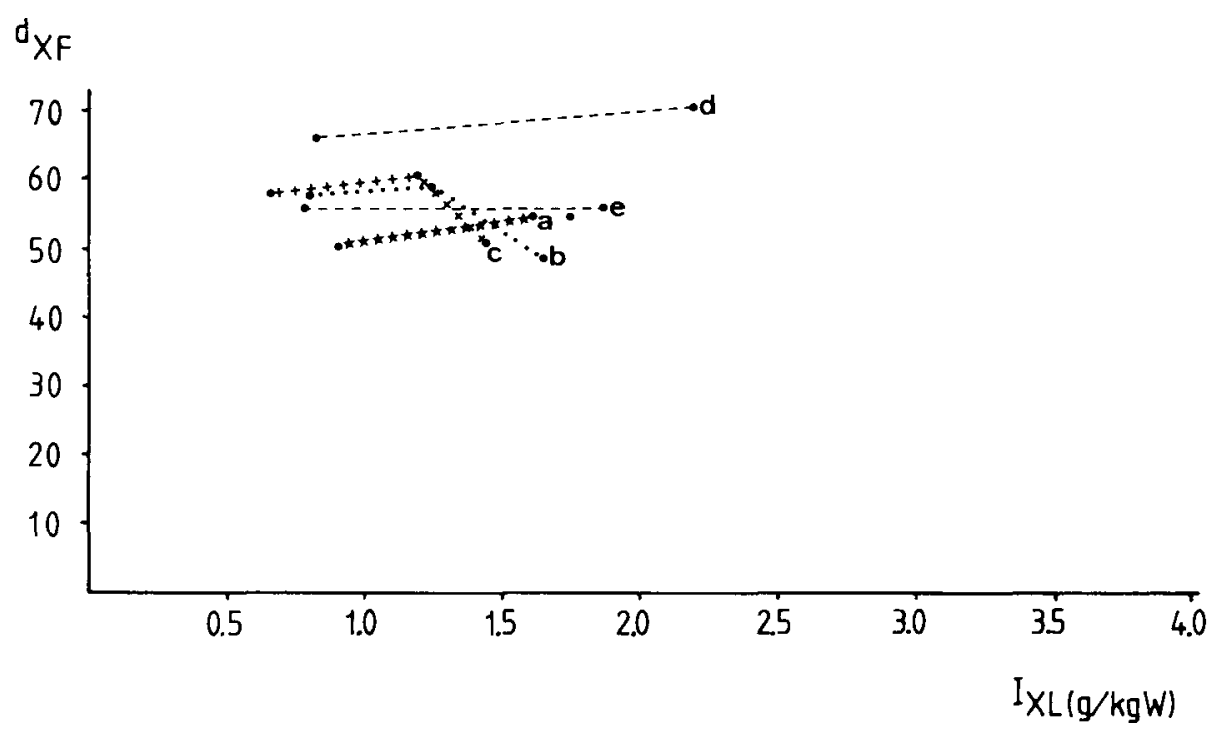

Fig. 1b. Effect of fat supplement on digestibility of fibre $\left(d_{X F}\right)$ by dairy cows versus lipid consumption $\left(\mathrm{I}_{\mathrm{XL}}\right)$ in $\mathrm{g} / \mathrm{kg}$ live weight. (From: Rohr et al., 1978: $\mathrm{a}=$ soya oil, $\mathrm{b}=\operatorname{cocosfat,} \mathrm{c}=$ animal tallow and this study: $\mathrm{d}, \mathrm{e}=$ animal tallow). 
son between the estimated digestibility of the cattle rations at maintenance and the measured digestibility with dairy cows at the production level. The size of the depression was moderate compared to values reported in the literature and fairly well comparable to the average depression ( $1.8 \%$ per unit increase of feeding level) of metabolizable energy content due to increased level of feeding as assumed in the new Dutch feed evaluation system (van Es, 1978). The slightly higher figures for XP agreed with the results of Schiemann et al. (1972). Moreover, differences between treatments were not significant.

Experiments with animal fat as a supplement did not always show a depression of crude fibre digestibility $\left(d_{\mathrm{XF}}\right)$ as reported by Devendra \& Lewis (1974) with sheep. When plotting the digestibility against the amount of fat (total lipids) in the diet per unit of body weight $\left(\mathrm{g} / \mathrm{kg}\right.$ ) (Fig. 1a, 1b) it is shown that only a depression of $\mathrm{d}_{\mathrm{XF}}$ was found at higher levels of supplementation (Dijkstra, 1969; Buysse, 1962; Rohr et al., 1978), whereas at low levels $d_{X F}$ hardly changed or even increased. Although Palmquist \& Conrad did not measure $d_{\mathrm{XF}}$ in their experiments the digestibility of ADF suggested an increase in the first level of supplementation or over the whole range (Fig. 2). Similar results were also found in our own experiments. Rohr et al. (1978) could not detect a depression with soya bean oil and neither could we. This led to the impression that results of trials with sheep and cattle can disagree with each other. The reason for this is not clear, but it seems to be partly due to the forage-to-concentrates ratio (Dijkstra, 1969; Rohr et al., 1978) and probably also to the level of feeding. In our experiments with dairy cows, where up to $67 \%$ of total dry matter in the ration was provided by the concentrate mixture, the large quantities of easily fermentable carbohydrates ingested may have affected the rumen flora resulting in a

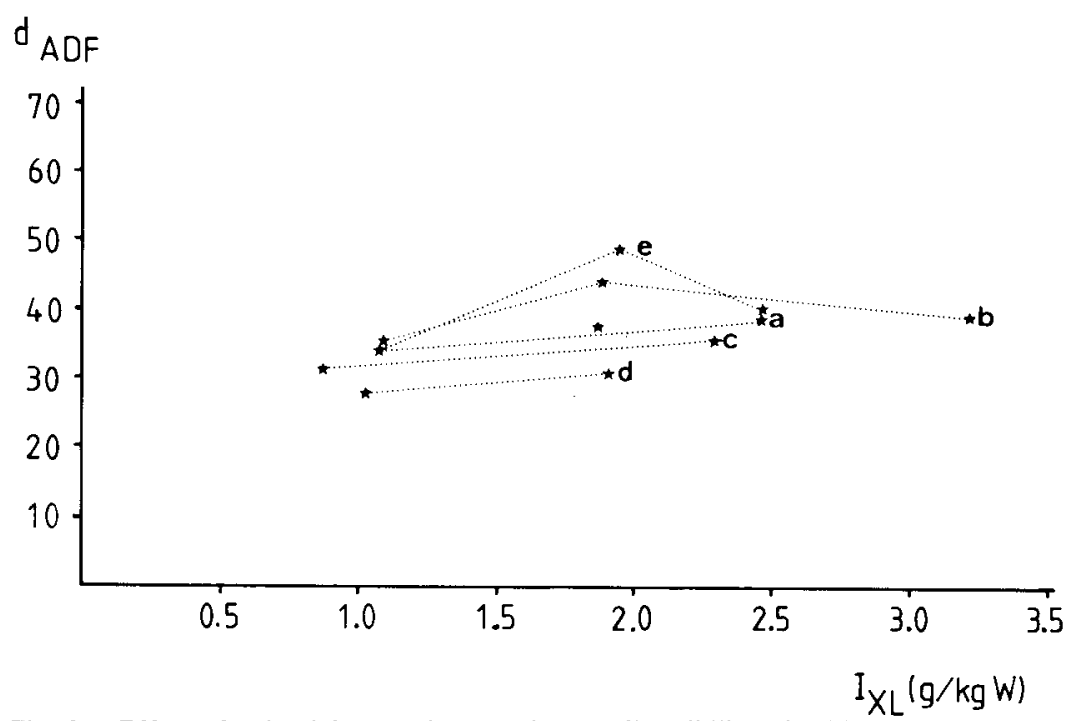

Fig. 2. Effect of animal fat supplementation on digestibility of acid detergent fibre $\left(\mathrm{d}_{\mathrm{ADF}}\right)$ versus the amount of lipids consumed by cows per $\mathrm{kg}$ live weight $\left(\mathrm{I}_{\mathrm{XL}}\right)$ in $\mathrm{g} / \mathrm{kg}$. (From: Palmquist \& Conrad, 1978: b, c, d and Palmquist \& Conrad, 1980: a, e). 
Table 5. Metabolizability $(\mathrm{q}=100 \mathrm{ME} / \mathrm{IE})$, and daily losses as urine and as methane in $\mathrm{MJ}$ and relative to energy intake (IE).

\begin{tabular}{|c|c|c|c|c|c|}
\hline \multirow[t]{2}{*}{ Ration } & \multicolumn{2}{|c|}{ Methane energy } & \multicolumn{2}{|c|}{ Urine energy } & \multirow{2}{*}{$\begin{array}{l}q \\
(\%)\end{array}$} \\
\hline & $\overline{\mathrm{MJ}}$ & $\%$ of IE & $\overline{\mathrm{MJ}}$ & $\%$ of IE & \\
\hline $\mathrm{C} 1$ & 18.4 & 5.9 & 14.1 & 4.5 & 61.74 \\
\hline $\mathrm{Tl}$ & 17.2 & $5.3^{*}$ & 14.7 & 4.5 & $63.42^{*}$ \\
\hline $\mathrm{S}$ & 15.9 & $5.0^{*}$ & 14.1 & 4.4 & 62.64 \\
\hline $\mathrm{C} 2$ & 18.4 & 6.5 & 11.4 & 4,0 & 62.62 \\
\hline $\mathrm{T} 2$ & 17.5 & $6.0^{*}$ & 11.7 & 4.0 & $65.79 *$ \\
\hline
\end{tabular}

* Significantly different from control treatment $(\mathrm{P}<0.05)$.

substantially reduced digestion of structural carbohydrates. If the fat added in such a situation retards the fermentation of the easily fermentable carbohydrates to some extent the effect of fat supplementation on digestibility of XF may even be positive. This possible explanation for the contradictory results is studied at our Institute with re-entrant cannulated lactating cows.

\section{Metabolizability}

Losses as urine and methane are presented in Table 5. Between treatments within experiments no significant differences in urinary losses were observed, but the fat/oil supplement caused lower relative methane-energy losses. Czerkawski et al. (1966) showed decreases in $\mathrm{CH}_{4}$ losses of 14-16\% of the energy supplied by infusion of fatty acids (oleic, linoleic and linolenic). The metabolizability differed significantly only between the tallow-supplemented and the control diet.

Rumen fermentation studies with only one fistulated animal in experiment I did not show important differences. On the diets $\mathrm{C} 1, \mathrm{~T} 1$ and $\mathrm{S}$ the $\mathrm{pH}$ of rumen fluid, measured 16 times between $05 \mathrm{~h} 00$ and $15 \mathrm{~h} 00$ was on average $6.6,6.5$ and 6.5 respectively. The acetate/propionate ratio slightly decreased due to fat/oil supplementation from 2.76 for $\mathrm{C} 1$ to 2.67 and 2.51 for $\mathrm{T} 1$ and $\mathrm{S}$, respectively.

Also the slightly lower $\mathrm{CH}_{4}$ losses on fat-supplemented diets could indicate some changes in rumen fermentation. However, this contribution only leads to a minor improvement of energy utilization as its size was approximately $1 \%$ of ME intake. The reduction in methane energy losses on the tallow treatment was ony 3-5 \% of the energy supplied by the fat, but on the soya bean oil treatment a reduction of $12 \%$ of the energy supplied by the oil agreed well with the figures which Czerkawski et al. (1966) obtained with supplementation of a sheep diet with unsaturated fatty acids.

\section{Utilization of metabolizable energy}

Daily milk yield, concentration of fat and protein in milk and the body weight of the animals are shown in Table 6. The tallow supplementation tended to increase the production of milk and milk energy, but with a simultaneous decrease of milk fat 
Table 6. Daily yield and composition of milk and body weight of the cows; average of 6 cows per treatment.

\begin{tabular}{llllll}
\hline Treatment & $\begin{array}{l}\text { Weight } \\
(\mathrm{kg})\end{array}$ & \multicolumn{2}{l}{ Milk production } & \multicolumn{2}{l}{$\begin{array}{l}\text { Milk energy } \\
(\mathrm{MJ} / \text { day })\end{array}$} \\
\cline { 3 - 5 } $\mathrm{kg} /$ day & fat $(\%)$ & $\mathrm{N} \times 6.37(\%)$ & \\
$\mathrm{C} 1$ & 589 & 24.1 & 3.84 & 3.21 & 69.9 \\
$\mathrm{~T} 1$ & 597 & 26.4 & 3.65 & 2.99 & 74.2 \\
$\mathrm{~S}$ & 595 & 26.5 & 2.67 & 3.08 & 65.4 \\
$\mathrm{C} 2$ & 566 & 20.7 & 4.02 & 3.03 & 63.5 \\
$\mathrm{~T} 2$ & 560 & 23.0 & 3.74 & 2.89 & 68.1 \\
\hline
\end{tabular}

and milk protein percentages; milk energy produced was not significantly changed. The reason for the lower protein concentration in milk is unknown, and although the relative lower proportion of carbohydrates in the fat-supplemented diet might have reduced the microbial protein synthesis in the rumen, the protein content of the concentrates was supposed to be high enough to provide a sufficient amount of absorbable protein/amino acids to the animal. The soya bean oil supplement reduced fat percentage and energy produced as milk.

Utilization of energy can be studied in different ways. For dairy cattle it will be important to know whether the metabolizable energy supplied above maintenance requirement is utilized for milk production or for body reserve formation and how efficient these processes are. In a latin square or a change-over trial with a very limited number of cows and rather short experimental periods, like in this energy balance study, it is difficult to study a preferential use of ME for production of milk or body reserve tissue. Feeding trials with experimental periods of several weeks or months are more suitable for such an investigation. The efficiency of utilization of energy, however, can be studied better by means of energy balance experiments, as in such experiments each of the various losses and depositions is measured.

Table 7. Utilization of metabolizable (ME) and of gross energy (IE) taken in. Net energy for maintenance assumed to be $293 \mathrm{~kJ} / \mathrm{kg}^{3 / 4}$ body weight.

\begin{tabular}{lllll} 
& IE & ME & $\mathbf{k}^{1}$ & $\mathrm{e}^{2}$ \\
& $(\mathrm{MJ} /$ day $)$ & (MJ/day) & $\%$ & \\
$\mathrm{C1}$ & 313 & 193 & 58.3 & 36.0 \\
$\mathrm{~T} 1$ & 325 & 206 & 60.1 & 38.1 \\
$\mathrm{~S}$ & 320 & 201 & 58.1 & 36.4 \\
$\mathrm{C} 2$ & 283 & 177 & 56.9 & 35.6 \\
$\mathrm{~T} 2$ & 294 & 194 & $59.6^{*}$ & $39.2^{*}$ \\
\hline
\end{tabular}

* Significantly different from control treatment $(\mathrm{P}<0.05)$.

$1 \mathrm{k}=$ (net energy in milk + retained energy + net energy for maintenance) $/ \mathrm{ME} \times 100$.

$2 \mathrm{e}=\mathrm{k} \times \mathrm{q}=$ total net energy $/ \mathrm{IE} \times 100$. 
By assuming for the net energy for maintenance a constant value of $293 \mathrm{~kJ} / \mathrm{kg}^{3 / 4}$ (van Es, 1978) it is possible to compute the efficiency of utilization of metabolizable (k) and of gross (e) energy (Table 7). This assumption of a constant value was very acceptable in this comparison of the rations within experiments as they were designed as a latin square or a change-over trial and based on a within cow comparison. Also within cows there were only minor differences in amount and quality of ME between rations. Total net energy equals the energy in milk + positive (or 0.8 negative) energy balance + net energy for maintenance. Also the net energy produced in milk and body tissue was plotted against ME intake, both expressed per unit metabolic body weight (Fig. 3). Analysis of variance did not show significant differences between diets within experiments. Compared to the equation described by van Es (1978), which equation is used in the Dutch feed evaluation system, the average deviation from the regression line was $-45.2,-24.0$ and -54.8 for C1, T1 and $\mathrm{S}$, respectively, and -68.0 and $-43.1 \mathrm{~kJ} / \mathrm{kg}^{3 / 4}$ for $\mathrm{C} 2$ and $\mathrm{T} 2$ respectively. None of these figures were deviating significantly from the values predicted by the regression equation and also between treatments no significant differences were observed.

Only in the second experiment a significant difference in utilization of ME ( $\mathrm{k}$ value in Table 7) could be detected in favour of the tallow-supplemented treatment. In Fig. 2 is shown that the values of T1 and T2 tended to deviate slightly less than control from the regression equation introduced by van Es (1978). From a biochemical point of view conversion of absorbed fats or fatty acids into milk or body fat is more efficient than conversion of carbohydrates into such fats. Moreover, ingested fat undergoes smaller losses in the rumen than carbohydrates, so this agrees with the observed tendency.

In Fig. 4 it was studied if the retained energy in body tissue per $W^{3 / 4}\left(R^{*}\right)$ was correlated with treatment and the utilization of metabolizable energy. Although the fat-supplement treatments showed higher $\mathrm{RE}^{*}$ values no significant increase or decrease of the deviation from regression was found with increasing $R^{*}$.

\section{Efficiency of utilization of gross energy}

The average efficiency of utilization of gross energy, expressed as a percentage in Table 7, was 36.0, 38.1 and 36.4 for $\mathrm{C} 1, \mathrm{~T} 1$ and $\mathrm{S}$ and 35.6 and 39.2 for $\mathrm{C} 2$ and T2 respectively. Only the difference between $\mathrm{C} 2$ and $\mathrm{T} 2$ was statistically significant ( $P$ $<0.05$ ). No distinction between net energy in milk and as body reserve tissue is made although the farmer will be mainly interested in the milk output potential of the feed, because this type of experiment is not well suited to study the effect of fat supplementation on milk production. The influence of fat addition to the concentrates of the second balance experiment $(\mathrm{C} 2, \mathrm{~T} 2)$ on milk yield was studied in our Institute by means of a feeding trial carried out with high-yielding cows in early lactation. This feeding trial showed a positive effect of fat supplementation on milk yield and production of fat-corrected milk (Rijpkema et al., 1980), as was also shown by Palmquist \& Conrad $(1978,1980)$ and others. It is promising especially for practice that feeding trials show a response in milk output in early lactation as a result of a higher energy input due to fat supplementation.

From the literature and these experiments it will be clear that not all types of fat 


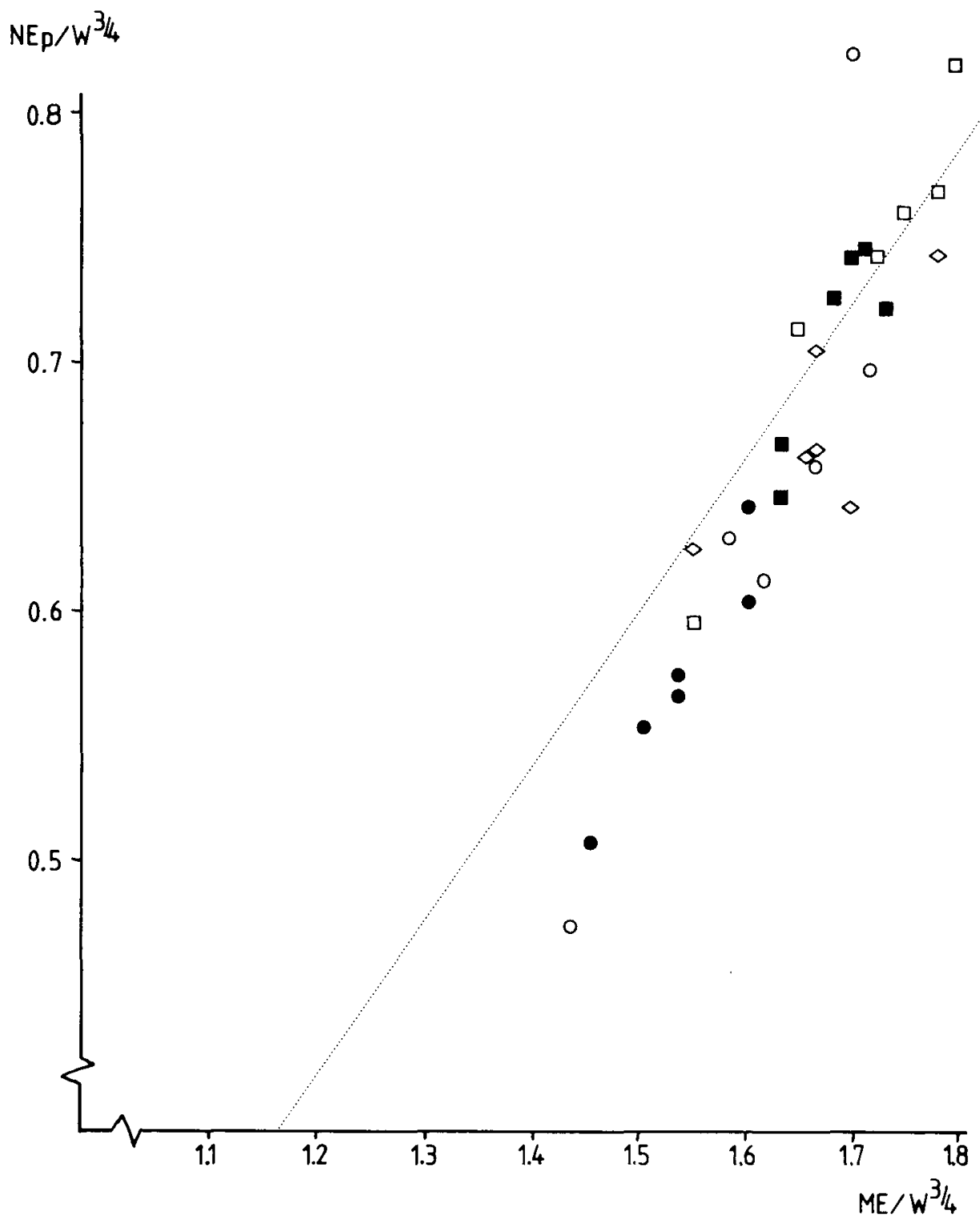

Fig. 3. Utilization of metabolizable energy $\left(\mathrm{ME} / \mathrm{W}^{3 / 2}\right)$ in productive net energy milk and body reserves $\left(\mathrm{NE}_{\mathrm{p}} / \mathrm{W}^{3 / 4}\right.$ ) (in $\mathrm{kJ} / \mathrm{kg}^{3 / 4}$ ). Dotted line represents the equation from van Es (1978), used in the Dutch feed evaluation system: $\mathrm{y}=0.6 \mathrm{x}-293$. Treatments: $O=\mathrm{C} 1 ; \square=\mathrm{T} 1 ; 0=\mathrm{S} ; \bullet=\mathrm{C} 2 ; \boldsymbol{\square}=\mathrm{T} 2$. 
Y. VAN DER HONING ET AL.

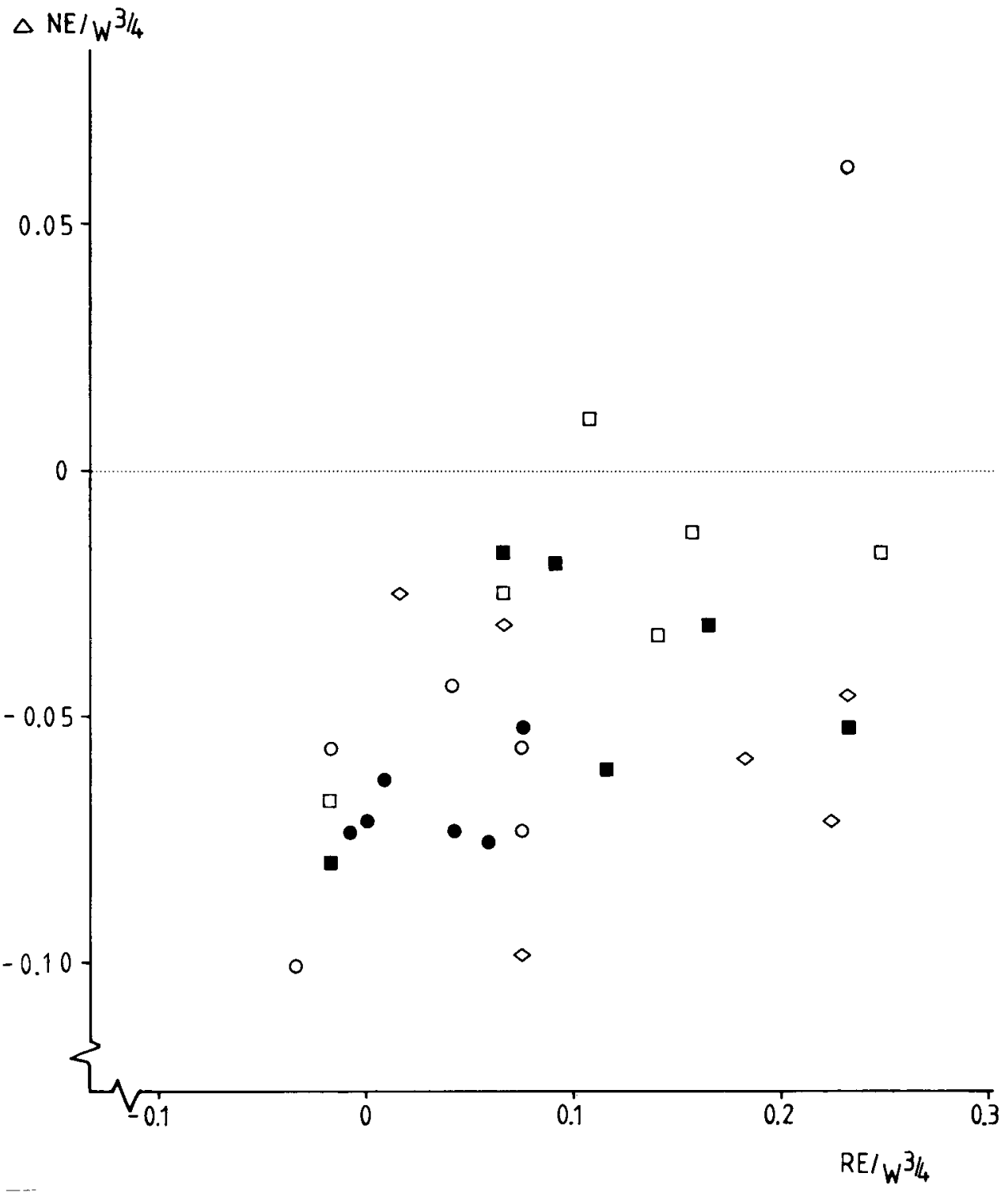

Fig. 4. Deviation ( $\Delta$ ) from regression equation, predicting net energy from $M E / W^{3 / 4}$ according to van Es (1978), versus the energy retention $\left(\mathrm{RE} / \mathrm{W}^{3 / 4}\right)$ in $\mathrm{kJ} / \mathrm{kg}^{3 / 4}$. Treatments: $\bigcirc=\mathrm{Cl} ; \square=\mathrm{Tl} ; \diamond=\mathrm{S} ; \bullet=$ $\mathrm{C} 2 ; \mathbf{0}=\mathrm{T} 2$. 
or oil may result in a similar positive effect on energy balance and/or milk production as found in our experiments with a good quality tallow. The negative effect of soya bean oil on milk fat percentage and milk fat quantity as well as depressions of digestibility, as reported by Rohr et al. (1978), probably indicate that several factors may influence the result of fat supplementation and that it will be difficult to predict the effect. The recently published results of Banks et al. (1980a, b) show that, besides feeding frequency and method of inclusion of soya bean oil, also the forage in the diet could be a factor that determines the effect of soya bean oil on the milk fat production. However, the result of a good quality animal fat such as tallow appeared to be positive in more than one experiment and place of experimentation.

\section{Conclusion}

Supplementation of a concentrate-mixture with 5-7\% tallow or $5 \%$ soya bean oil did not significantly depress apparent digestibility of energy and crude fibre in diets fed to productive cows.

Fat supplementation slightly lowered the losses of energy as methane.

Efficiency of utilization of metabolizable energy for maintenance, milk production and body reserves was not significantly different between treatments. Effect of level of feeding calculated from a sheep-cow comparison was fairly similar to the average figure in the Dutch feed evaluation system. The utilization of ME from the diets studied was not significantly deviating from the regression equations of the Dutch system, but most values tended to be slightly lower especially for the control diets.

Soya bean oil depressed the milk fat percentage and the energy in milk produced. Results of feeding trials with dairy cattle receiving good quality animal tallow or a comparable fat supplement in a concentrate-rich diet supported our opinion that energy from fat can contribute successfully to the production of dairy cows.

\section{Acknowledgements}

The authors gratefully acknowledge the contribution of all who co-operated with us in this study. Thanks are due to Mr R. Terluin and his staff in performing the animal trials and $\mathrm{Mr}$ A. Nijenhuis and his staff for the chemical analyses.

\section{References}

Banks, W., J. L. Clapperton \& M. E. Kelly, 1980a. Effect of oil-enriched diets on the milk yield and composition, and on the composition and physical properties of the milk fat, of dairy cows receiving a basal ration of grass silage. J. Dairy Res. 47: 227-285.

Banks, W., J. L. Clapperton, M. E. Kelly, A. G. Wilson \& R. J. M. Crawford, 1980b. The yield, fatty acid composition and physical properties of milk fat obtained by feeding soya oil to dairy cows. J. Sci. Fd Agric. 31: 368-374.

Binnerts, W. M., A. Th. van 't Klooster \& A. M. Frens, 1968. Soluble chromium indicator measured by atomic absorption in digestion experiments. Vet. Rec. 82: 470. 


\section{Y. VAN DER HONING ET AL.}

Broster, W. H. \& H. Swan, 1979. Feeding strategy for the high yielding dairy cow. EAAP-Publ. 25. Granada Publishing Ltd. London.

Buysse, F. X., 1962. De invloed van grotere vethoeveelheden op de verteerbaarheid van de voedende bestanddelen, in 't bijzonder van de ruwe celstof, bij herkauwers (schapen). Landbouwtijdschrift 15: 371-380.

Cottijn, B. G., F. X. Buysse \& Ch. V. Boucqué, 1971. The effect of linseed oil fatty acids on digestibility and rumen fermentation. Z. Tierphys. Tierernahr. Futtermittelkd. 27: 252-259.

Czerkawski, W., K. L. Blaxter \& F. W. Wainman, 1966. The metabolism of oleic, linoleic and linolenic acids by sheep with reference to their effects on methane production. Br. J. Nutr. 20: 349-362.

Demeijer, D. J., C. J. van Nevel, H. K. Henderickx \& J. Martin, 1969. The effect of unsaturated fatty acids upon methane and propionic acid in the rumen. Proceedings of the 4th Symposium on the Energy Metabolism, EAAP No 12: 139-147. Oriel Press, Newcastle upon Tyne.

Devendra, C. \& D. Lewis, 1974. The interaction between dietary lipids and fibre in sheep. Malaysian Agric. Res. 3: 163-176.

Dijkstra, N. D., 1969. Influence of supplemented animal fats upon digestibility of ration components by ruminants. Neth. J. agric. Sci. 17: 27-40.

Es, A. J. H. van, 1978. Feed evaluation for ruminants. 1. The systems in use from 1977 onwards in the Netherlands. Livestock Prod. Sci. 5: 331-345.

Johnson, R. R. \& K. E. McClure, 1973. High fat rations for ruminants. II. Effects of fat added to corn plant material prior to ensiling on digestibility and intake of the silage. J. Animal Sci. 36: 397-407.

Lough, A. K., 1975. Aspects of lipid digestion and absorption in the ruminant. In: K. Rommel, H. Goebell \& R. Bohmer (Ed.), Lipid adsorption: Biochemical and clinical aspects, p. 255-281.

Palmquist, D. L., 1975. A kinetic concept of lipid transport in ruminants. A review. J. Dairy Sci. 59: 355-363.

Palmquist, D. L., 1978. High fat dairy rations. Proc. Cornell Nutr. Conf. Feed Manufacturers 1978: 112-117.

Palmquist, D. L. \& H. R. Conrad, 1978. High fat rations for dairy cows. Effects on feed intake, milk and fat production, and plasma metabolites. J. Dairy Sci. 61: 890-901.

Palmquist, D. L. \& H. R. Conrad, 1980. High fat rations for dairy cows. Tallow and hydrolyzed blended fat at two intakes. J. Dairy Sci. 63: 391-395.

Rohr, K., R. Daenicke \& H. J. Oslage, 1978. Untersuchungen über den Einfluss verschiedener Fettbeimischungen zum Futter auf Stoffwechsel und Leistung von Milchkühen. Landbauforsch. Völkenrode 28: 139-150.

Rijpkema, Y. S. \& H. de Visser, 1980. Utilization and nutritive value of existing and newly introduced feedstuffs for ruminants. Annual report 1979. Institute for Livestock Feeding and Nutrition Research (IVVO), Lelystad, p. 6-7.

Schiemann, R., K. Nehring, L. Hoffmann, W. Jentsch \& A. Chudy, 1972. Energetische Futterbewertung und Energienormen. VEB Deutscher Landwirtschaftsverlag, Berlin, p. 102-108.

Vanschoubroeck, F. X., 1966. The utilization of fats in animal nutrition. World Congress Animal Nutr. 1: $217-262$. 